\title{
Reforming to Please: A Comprehensive Explanation for Non-Exit from the European Court of Human Rights
}

\author{
Hubert Smekal* and Nino Tsereteli**
}

\begin{abstract}
States' growing dissatisfaction with the performance of the European Court of Human Rights - Governments' commitment to reform process - Threats of exit that failed to materialise - Adaptation of Hirschman's exit-voice-loyalty framework to explain states' non-exit from the European Court of Human Rights - Sufficiently effective voice, manifestations of loyalty, and high costs of exit as possible reasons behind non-exit - Governments' inability to achieve change in the Court's practice unilaterally - Divergent perceptions and expectations of governments - Court's responsiveness to governments' concerns - Showing the importance of cautious, incremental changes to accommodate diverse governmental expectations on the role of the European Court of Human Rights
\end{abstract}

\section{INTRODUCTION}

Brexit has sparked interest in state withdrawals from international organisations. Such exits are not as rare as they may seem at first sight, as the world witnessed around 200 withdrawals in the 70 years following World War Two. ${ }^{1}$

*Hubert Smekal (hubert.smekal@law.muni.cz) is a senior researcher at Judicial Studies Institute, Masaryk University, Brno, and a lecturer at Maynooth University.

**Nino Tsereteli (Nino.Tsereteli@law.muni.cz) is a senior researcher at Judicial Studies Institute, Masaryk University, Brno.

The research leading to this article has received funding from the European Research Council (ERC) under the European Union's Horizon 2020 research and innovation programme (INFINITY, grant agreement no. 101002660). We would like to thank to Bríd Ní Ghráinne, Stefan Voigt, our colleagues at Judicial Studies Institute in Brno and discussants at the 2019 ECPR General Conference in Wroclaw. We are grateful to the reviewers for very insightful and constructive comments.

${ }^{1}$ I. von Borzyskowski and F. Vabulas, 'Hello, Goodbye: When Do States Withdraw from International Organizations?', 14 The Review of International Organizations (2019) p. 335 at p. 339.

European Constitutional Law Review, 17: 664-687, 2021

(C) The Author(s), 2021. Published by Cambridge University Press on behalf of European Constitutional Law Review. This is an Open Access article, distributed under the terms of the Creative Commons Attribution licence (http://creativecommons.org/licenses/by/4.0/), which permits unrestricted re-use, distribution, and reproduction in any medium, provided the original work is properly cited. doi:10.1017/S1574019621000377 
International courts have not been immune to exits - or threats thereof - either. Their growing influence in recent decades has triggered governmental resistance. ${ }^{2}$ The opposition manifested itself in hostile rhetoric, as well as refusals to cooperate or implement judgments. Governments have expressed dissatisfaction through blocking appointments, withholding funds and making efforts to constrain international courts through reforms. ${ }^{3}$ Governments have also made attempts to establish mechanisms alternative to the international courts they were frustrated by. ${ }^{4}$ Some went so far as to threaten to leave the courts. ${ }^{5}$ Some of those threats have eventually materialised. ${ }^{6}$

The European Court of Human Rights (the Court), as a court giving access to individuals and annually attracting tens of thousands of applications, deciding on sensitive and important issues, especially in inter-state disputes, and routinely issuing judgments that call for systemic changes in national systems, ${ }^{7}$ has been at particularly high risk of governmental withdrawals. Governments have been vocal about their dissatisfaction with the performance of the Court. Some questioned its efficiency and effectiveness because of the massive backlog of applications. Others accused the Court of overstepping its competencies and interfering in states' domaine réservé. Two governments (the UK and the Russian Federation) even voiced threats to leave, ${ }^{8}$ and Switzerland held a referendum

${ }^{2}$ See special issue of the International Journal of Law in Context 'Resistance to International Courts' (2018, Vol. 14(2)); E. Voeten, 'Populism and Backlashes against International Courts', 18 Perspectives on Politics (2020) p. 407.

3J. Pauwelyn and R.J. Hamilton, 'Exit from International Tribunals', 9 Journal of International Dispute Settlement (2018) p. 679.

${ }^{4}$ See E.Y. Omorogbe, 'The Crisis of International Criminal Law in Africa: A Regional Regime in Response?', 66 Netherlands International Law Review (2019) p. 294.

${ }^{5}$ F. Boehme, 'Exit, Voice and Loyalty: State Rhetoric about the International Criminal Court', 22 The International Journal of Human Rights (2018) p. 420; J. Petrov, 'The Populist Challenge to the European Court of Human Rights', 18 International Journal of Constitutional Law (2020) p. 476.

${ }^{6}$ For an overview of state efforts to exit, see Pauwelyn and Hamilton, supra n. 3. See also M. Ssenyonjo, 'State Withdrawal Notifications from the Rome Statute of the International Criminal Court: South Africa, Burundi and the Gambia', 29 Criminal Law Forum (2018) p. 63; X. Soley and S. Steininger, 'Parting Ways or Lashing Back? Withdrawals, Backlash and the Inter-American Court of Human Rights', 14 International Journal of Law in Context (2018) p. 237.

${ }^{7} \mathrm{H}$. Keller and A. Stone Sweet (eds.), A Europe of Rights: The Impact of the ECHR on National Legal Systems (Oxford University Press 2008); H. Smekal and K. Šipulová, 'DH v Czech Republic Six Years Later: On the Power of an International Human Rights Court to Push Through Systemic Change', 32 Netherlands Quarterly of Human Rights (2014) p. 288.

${ }^{8} \mathrm{~N}$. Watt, 'Cameron Refuses to Rule out Leaving European Convention on Human Rights', The Guardian, 3 June 2015, 〈https://www.theguardian.com/law/2015/jun/03/cameron-refuses-to-ruleout-leaving-european-convention-on-human-rights , visited 4 November 2021; 'Russia Will Quit 
on the 'Swiss law, not foreign judges' initiative9 which could have had repercussions for the Swiss position towards the Court. However, no exits followed.

This leaves us with a puzzle: why do states that threaten to exit from the Court ultimately choose not to? Why is it that most states will not consider exit, even in the case of a high level of dissatisfaction with the Court's performance? This article contributes to understanding and solving this puzzle by identifying factors that explain the non-exit of governments. For this purpose, we have adapted Hirschman's exit-voice-loyalty framework. ${ }^{10}$ The said framework concerned domestic situations involving the decline in organisations' performance. However, while adjusted to accommodate contextual differences, its logic and vocabulary can be relied on to make sense of governments' responses to the perceived decline in the Court's performance ${ }^{11}$ and, more specifically, of their decisions to use voice rather than exit.

Drawing inspiration from Hirschman's framework, we provide a coherent explanation for non-exit, ${ }^{12}$ elaborating on three key factors behind governments' continued commitment to the Court: (a) (perceived) effectiveness of voice, which will be associated, for most governments, with success in keeping membership costs low; (b) high costs of exit (reputational and other losses associated with exit); (c) loyalty (attachment) to the Court or the values it was established to promote. We argue that all three factors can collectively help avoid exit. We contend that, unlike members or customers of the organisations to which Hirschman's framework was originally applied, dissatisfied governments will not contemplate exit at the onset of the (perceived) decline in the Court's performance. Even if the prospect of improvement is uncertain, loyalty to the Court and/or the high costs of

Council of Europe If Opponents Insist on Its Expulsion, Says Lavrov', TASS, 16 October 2018, 〈https://tass.com/politics/1026225〉, visited 4 November 2021.

${ }^{9} \mathrm{C}$. Kaempfer et al., 'Switzerland Rejects a Popular Initiative "Against Foreign Judges”', Opinio Juris, 17 December 2018, 〈http://opiniojuris.org/2018/12/17/switzerland-rejects-a-popularinitiative-against-foreign-judges/ $\rangle$, visited 4 November 2021.

${ }^{10}$ A.O. Hirschman, Exit, Voice, and Loyalty: Responses to Decline in Firms, Organizations, and States (Harvard University Press 1970).

${ }^{11}$ In a few instances, this framework has already been applied to international organisations and international courts: see Boehme, supra n. 5; J. Slapin, 'Exit, Voice, and Cooperation: Bargaining Power in International Organizations and Federal Systems', 21 Journal of Theoretical Politics (2009) p. 187.

${ }^{12}$ While a comprehensive explanation for non-exit is lacking, scholars have highlighted a few relevant factors. Particularly, it has been suggested that: (i) states are more likely to exit international courts that are self-standing as opposed to the ones that are embedded in larger organisations; (ii) states are more likely to exit if they do not have enough political capital to secure desired change. Another factor that mitigates resistance and arguably makes exit unlikely is the existence of constituencies that support international courts. See Pauwelyn and Hamilton, supra n. 3; Soley and Steininger, supra n. 6. 
exit from its jurisdiction can dissuade governments from leaving. Also, because governments are not simply beneficiaries of the Court's services and can influence it by altering its mandate or withholding funds essential for its operation, they may be inclined to use voice first. While not all expectations of governments can realistically be met, they will remain within the system if they conclude that voice has been sufficiently effective. In case of a deadlock in the reform process, which is likely where governments' perceptions of the Court's role greatly diverge, the Court's responsiveness and its ability to find creative solutions to the problems governments identified can be helpful in reducing the risk of exit. However, when faced with the conflicting expectations of governments, some of whom approve of its interventionist stance, while others call for self-restraint, the Court can only manage to avoid antagonising some of the governments by taking a careful, incremental approach to change.

Our theorising is supported by a structured study of governmental rhetoric and behaviour throughout the reform process that spanned the past decade. ${ }^{13} \mathrm{We}$ have analysed 226 governmental speeches from five intergovernmental conferences held between 2010 and $2018 .{ }^{14}$ In addition to those speeches, a number of other governmental statements made elsewhere have been incorporated into the analysis. Considering that the tone of governmental speeches at conferences is bound to be as soft and diplomatic as possible, looking beyond them allows governments' attitudes to be captured more accurately.

The Court is particularly well-suited for developing an empirically informed explanation for governments' reluctance to even consider exit despite considerable dissatisfaction with the Court's performance or to follow through on actual threats of exit. In contrast to other international courts that were similarly threatened, the Court actually managed to avoid exits, despite the often very sensitive content of its rulings. The study of a decade-long reform process provides ample opportunity to illustrate the factors that informed the choices made by governments at various stages of this process. While these statements might not fully capture the reform

\footnotetext{
${ }^{13}$ About the reform process, see L. Glas, 'From Interlaken to Copenhagen: What Has Become of the Proposals Aiming to Reform the Functioning of the European Court of Human Rights?', 20 Human Rights Law Review (2020) p. 121; L. Helfer, 'The Burdens and Benefits of Brighton', 1 ESIL Reflections (2012) p. 6; M.R. Madsen, 'Rebalancing European Human Rights: Has the Brighton Declaration Engendered a New Deal on Human Rights in Europe?', 9 Journal of International Dispute Settlement (2018) p. 199; H. Milner, 'Protocols No. 15 and 16 to the European Convention on Human Rights in the Context of the Perennial Process of Reform: A Long and Winding Road', 17 Zeitschrift Für Europarechtliche Studien (2014) p. 19; N. O'Meara, 'Reforming the European Court of Human Rights: The Impacts of Protocols 15 and 16 to the ECHR', in K.S. Ziegler et al. (eds.), The UK and European Human Rights. A Strained Relationship? (Hart Publishing 2018) p. 71.

${ }^{14}$ At each conference, over 40 governments made speeches (Brussels 43, Brighton 46, Interlaken 46, Izmir 44, and Copenhagen 47).
} 
dynamics, they can help to identify governments' thinking and expectations and whether, in their view, those expectations have been fulfilled as the reform progressed.

The article proceeds as follows. We first explain the basic tenets of Hirschman's framework and argue that its logic can be transposed to the context of the European Court of Human Rights. Then, we show how this logic manifests itself in the case of the Court. We demonstrate the perceived decline in the Court's performance and explain why governments chose voice over exit. The conclusion summarises the three factors identified and illustrates the broad applicability of these factors beyond the Court.

\section{The MAIN TENETS OF Hirschman's EXIT-VOICE-LOYALTY FRAMEWORK}

According to Hirschman, deterioration in the performance of organisations is typically reflected in an absolute or comparative deterioration in the quality of the product or service they provide. ${ }^{15}$ Members or customers of such organisations, dissatisfied with the organisation's performance and quality of product or service, ${ }^{16}$ can either use voice (i.e., express discontent, giving the organisation a chance to address their concerns and improve) or exit. ${ }^{17}$ These two courses of action are not mutually exclusive, however. It is possible for the members or customers of the organisation first to choose voice, but decide to exit later if the organisation's response is unsatisfactory. It is also possible for the members to exit, but continue using voice. ${ }^{18}$

Hirschman's framework helps identify factors that can lead to a postponement - or even the complete avoidance - of exit. According to Hirschman, members or customers of an organisation dissatisfied with its performance will typically choose exit over voice because it is less costly. However, under certain conditions, voice is likely to play an important role. Voice will be in a commanding position in the absence of competing organisations that provide similar products or services. ${ }^{19}$ Where exit (i.e a switch to a similar organisation or product) is possible, voice can still be chosen in light of the prospect of its effective use, where members or customers believe that they will be able to influence the organisation's

\footnotetext{
${ }^{15}$ Hirschman, supra n. 10, p. 4.

${ }^{16} \mathrm{~K}$. Dowding et al., 'Exit, Voice and Loyalty: Analytic and Empirical Developments', 37 European Journal of Political Research (2000) p. 475.

${ }^{17}$ Hirschman, supra n. 10, p. 4. For criticism of Hirschman's dichotomous framework that envisages two dominant mechanisms, exit and voice, see W.R. Clark et al., 'An Exit, Voice and Loyalty Model of Politics', 47 British Journal of Political Science (2017) p. 721.

${ }^{18}$ Dowding et al., supra n. 16.

${ }^{19}$ Hirschman, supra n. 10, p. 34, 40, 43, 76.
} 
management and secure change in practices, policies or outputs. The propensity to resort to voice increases with the invention of mechanisms that can communicate complaints cheaply and effectively. ${ }^{20}$

Some will stay with the under-performing organisation because of 'loyalty' (attachment to a product or an organisation), which is 'less rational' but 'far from wholly irrational'. ${ }^{21}$ Loyal members will 'stick' with an organisation notwithstanding the uncertainty of an improvement in performance. Loyalty can be particularly helpful to keep members in, where substitutes for the organisation or product/service it provides are available. Hirschman suggests that many of these 'loyalists' will actively participate in actions designed to change policies or practices (i.e. use voice), but 'some may simply refuse to exit and suffer in silence, confident that things will soon get better'. ${ }^{22} \mathrm{He}$ adds that 'an individual member can remain loyal without being influential itself, but hardly without the expectation that someone will act or something will happen to improve matters. ${ }^{23}$ Loyal members/customers can be reluctant to leave an organisation that produces public goods (i.e. the type of goods that all members of the community consume and benefit from, such as crime prevention or public health standards), despite dissatisfaction with that organisation. Exit can be avoided where members/customers believe that exit will lead to a further deterioration of the quality of the organisation's output, and this deterioration will affect them even after formal exit. Hence, they have a choice between using voice from within and using voice from the outside, after exit. ${ }^{24}$

\section{Adapting Hirschman's framework to the Court}

We contend that Hirschman's framework, after necessary adaptations, helps to make sense of governments' responses to a perceived decline in the Court's performance. Based on the framework, we suggest that governments' dissatisfaction with the Court's performance can trigger two main types of responses: governments may exit, or they may remain under the Court's jurisdiction and use voice (identify problems and seek change). ${ }^{25} \mathrm{We}$ posit that, unlike members or customers of the organisations to which Hirschman applied his framework, governments

\footnotetext{
${ }^{20}$ ibid., p. $30,37,43$.

${ }^{21}$ ibid., p. 38, 81 (an example Hirschman uses is the special attachment to football teams or political parties).

${ }^{22}$ ibid., p. $38,77,79-80$.

23 ibid., p. 78 .

${ }^{24}$ ibid., p. $98-100,104$.

${ }^{25}$ It is quite possible that not all states that stay part of the system will use voice. Some of them may simply be satisfied with the Court's performance and not seek change, or they may be dissatisfied but count on other governments to secure change.
} 
will not contemplate exiting the Court's jurisdiction immediately on noticing a decline in its performance. Their continued commitment to the Court and their inclination to use voice can be explained by the following three factors: (a) the belief that voice will be effective; (b) the high costs of exit; and (c) loyalty to the Court.

First, governments are not simply beneficiaries of the Court's services. While trusting the Court with the task it was established to carry out, ${ }^{26}$ they maintain a certain ownership of the system. In some ways, they are comparable to the board members, in a sense that they monitor the Court's activities and can react where, in their view, the Court has under-performed or exceeded its authority. They could seek to constrain or sanction the Court by limiting its jurisdiction through treaty amendment, altering its composition or withholding funds essential for its operation. ${ }^{27}$ They could also signal dissatisfaction with regard to the judgments requiring significant changes in national legal systems through criticism or noncompliance. They could voice discontent individually or collectively through the reform process (for example, intergovernmental conferences that culminate in declarations) or outside such process. Voice can manifest itself in threats of exit. ${ }^{28}$ The intensity of governments' efforts to secure change can vary, depending on the degree of dissatisfaction with the Court's performance and on the political capital enabling them to bring the international court 'back on track'.

Governments may reverse their initial choice of voice at a later stage, if they conclude that it was not sufficiently effective. Hence, the likelihood of exit may increase over time. The prospect of securing change hinges on how widely shared governments' concerns are and whether the Court is willing to accommodate these concerns and make adjustments in its practice. ${ }^{29}$ Governments may diverge in their perception of the Court's role and their expectations towards its performance: established democracies with good human rights records might welcome occasional external checks which can further fine-tune their human rights practices. New democracies might appreciate the Court's help in locking in their

\footnotetext{
${ }^{26}$ Under Art. 19 of the Convention, the Court was established 'to ensure the observance of the engagements undertaken by the High Contracting Parties in the Convention and the Protocols thereto'.

${ }^{27}$ L. Helfer and A.M. Slaughter, 'Why States Create International Tribunals: A Response to Professors Posner and Yoo', 93 California Law Review (2005) p. 952.

${ }^{28}$ Hirschman, supra n. 10 , p. 83, suggests that while the possibility of exit can reduce the willingness to use voice, it can also increase the ability of members of the organisation to use voice effectively. This will happen where there is a possibility of exit, but it is not too easy or too attractive. See also Clark et al., supra n. 17, p. 741-742; Slapin, supra n. 11, p. 190-192.

${ }^{29}$ International courts can be cautious about appearing too deferential to governments that have criticised them, as this could damage their legitimacy: Boehme, supra n. 5.
} 
liberal democratic orientation. ${ }^{30}$ States which consider their human rights performance adequate or those which do not aspire to improve domestic standards of human rights protection would appreciate judicial self-restraint.

The Court can afford to be assertive in relation to governments and successfully defend its practices, especially where governments are divided over what is appropriate. ${ }^{31}$ However, it may have to make some adjustments when faced with consensus among governments on the need for such adjustments. Where a particular government's concerns are not widely shared by others, the adoption of a treaty amendment or a political declaration aimed at securing the desired change in the Court's practice is unlikely. Political pressure on the Court will be reduced as a result, but the likelihood of a marginalised government's exit will increase down the line too. In case of a deadlock in the reform process due to variation in governments' perceptions of the Court's role and in their assessments of its performance, the Court's willingness and ability to develop creative solutions to the problems identified by governments can help avoid exit. ${ }^{32}$ When faced with governments' conflicting expectations, however, the Court may need to act cautiously and incrementally to avoid antagonising some of these governments and triggering exit. While not all expectations of all governments can realistically be met, at least some of their concerns have to be addressed satisfactorily through the reform process, so that they perceive their engagement with the Court to be sufficiently effective.

Second, governments may be deterred by the high costs of exit. As noted above, under Hirschman's framework, exit is the preferred option for members or customers dissatisfied with the organisation's performance, because it is typically costless or not as costly as voice. We argue that the costs of exiting the Court's jurisdiction are high enough to deter governments from leaving and can prompt them to use voice, even if the prospect of its effectiveness is uncertain. Costs of exit are high because of the absence of other courts that can provide the same service. ${ }^{33}$ A good reputation for the Court, emerging out of its convincing judgments or other output, also increases the costs of exit, since governments will find it difficult to justify leaving its jurisdiction without calling their own human rights commitments into question. The decline in the Court's performance does

\footnotetext{
${ }^{30}$ A. Moravcsik, 'The Origins of Human Rights Regimes: Democratic Delegation in Postwar Europe', 54 International Organization (2000) p. 217.

${ }^{31}$ T. Squatrito et al., 'A Framework for Evaluating the Performance of International Courts and Tribunals', in T. Squatrito et al. (eds.), The Performance of International Courts and Tribunals (Cambridge University Press 2018) p. 3 at p. 6-9, 13.

${ }^{32}$ Some of these changes can be implemented through changing the Rules of the Court. The Plenary Court amends those Rules.

${ }^{33}$ As a minimum, international courts are seen as mechanisms of dispute settlement: A. Von Bogdandy and I. Venzke, 'On the Functions of International Courts: An Appraisal in Light of Their Burgeoning Public Authority', 26 Leiden Journal of International Law (2013) p. 49.
} 
not necessarily undermine its reputation, especially if governments contribute to this decline by their failure to fulfil commitments under the European Convention on Human Rights and their failure to properly implement the Court's judgments. The fewer the governments that blame the Court for the malperformance, the more difficult it is to justify exit. Exit may undermine the reputation of the state as a stable trustworthy partner capable of fulfilling its commitments. ${ }^{34}$

If governments do not succeed in changing the system, the costs of exit can still deter them from leaving, unless the costs of membership become even higher. Costs of exit will be high, especially if remaining under the Court's jurisdiction is demanded by other governments as a condition of political or other cooperation. The Court may also help increase the costs of exit if it improves the quality of its outputs. The deterioration in quality of the Court's outputs could, however, undermine its reputation and force governments to reconsider being part of the system.

Third, loyalty to the Court, or to the values it was established to promote, can prompt governments dissatisfied with the Court's performance to postpone exit and use voice, notwithstanding the uncertainty that improvement in performance will occur. ${ }^{35}$ Based on Hirschman's logic, we argue that loyalty can lead governments to active participation in actions designed to change the Court's practices or to staying silent, convinced that the situation will soon get better. Another loyaltydriven response which Hirschman's framework and its various adaptations have not identified, and which appears relevant, is the defence of the Court by a government against the use of voice by other governments that are, in the view of the former, 'harassing' and actually hindering rather than helping efforts at recovery. ${ }^{36}$

To sum up, our adaptation of Hirschman's framework identifies factors that can explain governments' choice of voice over exit. We suggest that it is unlikely that governments will seriously contemplate exit immediately on observing deterioration in Court's performance. This is because of: (a) the high costs of exit; (b) the governments' belief that voice will be effective; and (c) loyalty to the Court. Governments that are dissatisfied with the Court's performance and/or the ones that are loyal to the system are more likely to use voice, especially if they have sufficient political capital. Loyalty can also be a driving force behind other types of governmental responses, namely, defence of the Court from unnecessarily

\footnotetext{
${ }^{34}$ A.T. Guzman, How International Law Works: A Rational Choice Theory (Oxford University Press 2010).

${ }^{35}$ Hirschman, supra n. 10 , p. 38.

36 ibid., p. 31, admits that voice can be overdone, in a sense that 'the discontented customers or members could become so harassing that their protests would at some point hinder rather than help whatever efforts at recovery are undertaken.'
} 
hostile attacks. The likelihood of exit increases down the line if governments do not perceive voice as sufficiently effective.

The remaining sections illustrate how these three factors (costs of exit, the effectiveness of voice, and loyalty) appear to have shaped governmental responses to the perceived decline in the Court's performance. Admittedly, the government statements that we have accumulated do not fully and exhaustively capture the reasons for governments failing to leave; still, they are helpful in showing the plausibility of our theory.

\section{MAPPING GOVERNMENTAL RESPONSES TO (PERCEIVED) DECLINE IN THE COURT'S PERFORMANCE}

As noted above, governments dissatisfied with the Court's performance initiated the reform process instead of exiting. They remained committed to the reform as it progressed. Some governments had a more clearly defined agenda and sought change more proactively than others, e.g. by convening intergovernmental conferences. Five intergovernmental conferences were conducted between 2010 and 2018, in Interlaken (2010), Izmir (2011), Brighton (2012), Brussels (2015) and Copenhagen (2018). Initially, the reform agenda was primarily focused on the caseload crisis, ${ }^{37}$ created by overwhelmingly large numbers of clearly inadmissible applications and well-founded repetitive cases emerging out of states' failure to solve underlying problems. The Court's efficiency (capacity to process applications) and effectiveness (ability to facilitate changes in national laws and practices) emerged as key concerns in Interlaken and Izmir. ${ }^{38}$ In Brighton, the focus shifted to reflect the UK's concerns about the Court's lack of deference to well-performing and responsible national authorities. ${ }^{39}$ The UK problematised diversion by the Court of its limited resources to cases in which well-functioning bodies appeared to have applied the Convention responsibly and argued against substitution by

\footnotetext{
${ }^{37}$ The number of applications pending before the Court jumped from 10,000 in the year 2000 to almost 50,000 in 2008 and an alarming 160,000 in 2011: European Court of Human Rights, 'Some Facts and Figures 1998-2008', p. 4, 〈https://www.echr.coe.int/Documents/Facts_Figures_ 1998_2008_ENG.pdf), visited 4 November 2021; European Court of Human Rights, 'Analysis of Statistics 2018', p. 7 〈https://www.echr.coe.int/Documents/Stats_analysis_2018_ENG.pdf〉, visited 4 November 2021.

${ }^{38}$ Early in the process, governments called for strict, coherent and consistent application of admissibility criteria by the Court, and emphasised the need for clarity and consistency in the Court's case law. Such concerns came from Italy, Serbia, Bulgaria, Turkey, the Russian Federation, Greece, and a few others.

${ }^{39}$ The draft Brighton Declaration that leaked was criticised as it included a number of provisions restricting access to the Court or calling for deference to national courts on its part: O'Meara, supra n. 13.
} 
the Court of its judgment for that of 'reasonable national processes' ${ }^{40}$ At the Brussels Conference, the focus was again on the effective implementation of the Convention and execution of the Court's judgments. The Copenhagen Conference was marked by insistence on a dialogue between the Court and governments through employing a variety of formal and informal mechanisms, which could re-balance the system. ${ }^{41}$

The analysis of conference proceedings revealed a divergence in governments' identification of problems and solutions. While some governments called for giving the Court additional resources to enable it to handle the backlog, others argued that the Court had to use available resources more efficiently. While some governments problematised unsolved structural problems and supported the reinforcement of the Convention machinery for better exposure of implementation failures, those failing governments blamed the Court ${ }^{42}$ and used the reform process to block changes meant to highlight and sanction delays in implementation. This latter category would actually benefit from the below par performance of the

${ }^{40}$ D. Cameron, 'Speech on the European Court of Human Rights', gov.uk, 25 January 2012 〈https://www.gov.uk/government/speeches/speech-on-the-european-court-of-human-rights〉, visited 4 November 2021. The UK Government raised this point in Interlaken, Izmir and Brighton. Similarly, in Izmir, the Netherlands asked for 'more confidence' to be placed on the capacity of national proceedings, 'unless clear shortcomings have been demonstrated'. In Copenhagen, Switzerland suggested that the Court could 'reduce the intensity of its control, provided and to the extent that the national authorities have done their homework and applied the Convention'.

${ }^{41}$ Denmark, the Conference host, highlighted the need to strengthen the avenues for dialogue, inter alia, by improving access to third party interventions and by discussing developments in the case law of the Court. These proposals were viewed as means of re-balancing the system, exerting pressure on the Court and undermining its independence: A. Donald and P. Leach, 'A Wolf in Sheep's Clothing: Why the Draft Copenhagen Declaration Must Be Rewritten', EJIL: Talk!, 21 February 2018, 〈https://www.ejiltalk.org/a-wolf-in-sheeps-clothing-why-the-draft-copenhagendeclaration-must-be-rewritten/ $\rangle$, visited 4 November 2021; J. Gerards and S. Lambrecht, 'The Final Copenhagen Declaration: Fundamentally Improved with a Few Remaining Caveats', Strasbourg Observers, 18 April 2018, 〈https://strasbourgobservers.com/2018/04/18/the-finalcopenhagen-declaration-fundamentally-improved-with-a-few-remaining-caveats $/\rangle$, visited 4 November 2021; A.O. Jiménez, 'The Copenhagen Declaration: Are the Member States about to Pull the Teeth of the ECHR?', Verfassungsblog, 9 April 2018, 〈https://verfassungsblog.de/thecopenhagen-declaration-are-the-member-states-about-to-pull-the-teeth-of-the-echr/ $\rangle,$ visited 4 November 2021.

${ }^{42}$ As an example, in Brussels (2015), the Russian Federation argued that the Court exceeded its jurisdiction by issuing very detailed recommendations for the implementation of judgments. They expressed 'deep concerns with respect to the quality of judgments, some of which encroached upon the exclusive powers of the State Parties' and argued that 'execution problems encountered are caused by the fact that, in the judgments in these cases, the Court departs from the existing system of international case-law' making some of its judgments 'practically non-executable'. 
Convention machinery. In any case, because of such divisions, bolder proposals aimed at either strengthening or constraining this machinery were bound to fail.

This analysis of conference proceedings also revealed that not all governments who decided against exit used voice in the sense of criticising the Court and demanding change. Governments also regularly defended the Court against what they believed were improper uses of voice, i.e. the ones that were meant to damage or undermine the Court. In Interlaken, the Dutch representative argued: 'some have suggested that the Court itself is to blame for the problems it encounters... it would be ludicrous to point the finger at the Court. Neither can we blame the applicants for trying all legal avenues ... in the end, the responsibility for the functioning of the Court lies with us'. More recently, at the Copenhagen Conference, several governments expressed concern that proposed mechanisms of dialogue would be used to subject the Court to unnecessary political pressure and undermine its independence. A few argued that 'compromising and restricting the authority of the Court would be irresponsible', and that the 'authority and independence of the Court must never be put at risk'. ${ }^{43} \mathrm{~A}$ few governments welcomed the fact that the reform process avoided questioning the independence of the Court, the scope of its jurisdiction and the unconditional obligation of State Parties to implement the Court's judgments. ${ }^{44}$ The presence of such governments explains why the initial texts of some of the declarations that were rather constraining for the Court ${ }^{45}$ were eventually toned down. ${ }^{46}$

While speeches made at intergovernmental conferences help reveal governments' expectations regarding reform outcomes as well as their assessments of the progress made, the tone of these speeches is bound to be careful and diplomatic. The fact that these speeches did not mention the possibility of exit does not automatically mean that participating governments did not contemplate exit at some point or resort to the threat of exit. It emerges that the representatives of at least two governments (the UK and the Russian Federation) made such threats. In June 2015, the UK Prime Minister Cameron did not rule out withdrawal from the Convention if his proposals for change were rejected by the Court. ${ }^{47}$ Soon after, the Home Secretary, Theresa May, insisted that the UK would leave the jurisdiction of the Court. She argued that the Court prevented

\footnotetext{
${ }^{43}$ Sweden's statement at the Copenhagen Conference. Representatives of San Marino and Poland made a similar point.

${ }^{44}$ Representatives of Moldova, the Netherlands and Slovenia made these types of comments in Copenhagen.

${ }^{45}$ Donald and Leach, supra n. 41.

${ }^{46} \mathrm{Glas}$, supra n. 13.

${ }^{47}$ Watt, supra n. 8.
} 
the UK from deporting dangerous foreign nationals and did nothing to change the attitudes of governments like Russias. ${ }^{48}$ The opposition of the UK to the EU and the Court overlapped. However, it appears that the Brexit deal locked in the status quo surrounding the UK's relationship with the Court, forcing the UK to remain with the Convention as a basis for future cooperation with the EU.$^{49}$ Exit threats were voiced by the Russian political leaders too. ${ }^{50}$ However, none of these threats eventually materialised.

To sum up, it emerges that governments dissatisfied with the Court's performance contemplated exit and even issued threats that they would leave if their voices were not heard. However, as expected, they made such statements years into the reform process, signalling that exit was seen as a last resort. As regards the uses of voice, its focus and intensity varied from one government to another, depending on the reasons and extent of dissatisfaction as well as the capacity of particular governments to exert influence. It also emerged that governmental responses to the (perceived) decline in the Court's performance were more nuanced than Hirschman's framework might have suggested. Not all governments that decided against exit used voice. Some intervened to defend the Court, where they believed that other governments overdid voice and sought to undermine the Court through reform efforts.

\footnotetext{
${ }^{48}$ A. Asthana and R. Mason, 'UK Must Leave the European Convention on Human Rights, says Theresa May', The Guardian, 25 April 2016, 〈https://www.theguardian.com/politics/2016/apr/25/ uk-must-leave-european-convention-on-human-rights-theresa-may-eu-referendum $\rangle$, visited 4 November 2021.

${ }^{49}$ F. Cowell, 'Brexit Deal Locks the UK into the Continued Strasbourg Human Rights Membership', 17 January 2021, LSE Blog, 〈https://blogs.lse.ac.uk/brexit/2021/01/17/the-brexitdeal-locks-the-uk-into-continued-strasbourg-human-rights-court-membership/ $\rangle, \quad$ visited 4 November 2021.

${ }^{50}$ In his 2014 speech, Putin addressed the possibility of exit from the Court's jurisdiction and noted: 'The European Court of Human Rights is not a symbol of justice today. It turned into a simple instrument of exerting political pressure on Russia. Moreover, it constitutes a channel of intrusion into domestic affairs through judgments': Meeting with the Members of Political Factions in the State Duma, Yalta, 14 August 2014, 〈http://www.kremlin.ru/events/president/ news/46451 , visited 4 November 2021. In 2018, there were media reports about the Russian Government's intention to denounce the Convention, if the Court did not stop being political and did not become responsive: 'Media learnt that the Question of Denunciation of the European Convention of Human Rights by the Russian Federation is being considered', 1 March 2018, 〈https://www.rbc.ru/politics/01/03/2018/5a97b3e19a7947368eeb7b0a), visited 4 November 2021.
} 


\section{EXPLAINING CHOICES MADE BY GOVERNMENTS}

The purpose of this section is to apply our adaptation of Hirschman's framework to the relationship between the Court and national governments. We show how the three factors (effectiveness of voice, high costs of exit, and loyalty to the Court) work in practice to postpone and avoid governments' exit from the Court's jurisdiction.

\section{Effectiveness of voice}

Hirschman's framework suggested that the perceived effectiveness of voice can preclude or postpone exit. ${ }^{51}$ Following that logic, we argued that governments' decision not to exit and their use of voice is rooted in their expectation that the system can be changed from within. Governments will remain committed to reform if their expectations are met, as the reform progresses. Expectations will vary, and so will the ability of specific governments to ensure that these expectations are fulfilled. Overall, effectiveness is relative. Not all changes that governments call for will actually be implemented, but at least some should be, in order for those governments to remain part of the system.

The analysis of proceedings from five intergovernmental conferences revealed certain alignment in the governments' interests and agendas. Provisionally, three distinct groups of governments have emerged, based on the type of concerns on which they placed the most emphasis. As shown below, these groups framed problems differently and proposed solutions accordingly. Their continued commitment to the reform path hinged on the perceived effectiveness of their engagement in the reform process. This meant that at least some of the expectations had to be met. Because governments who are engaged in the reform process pursue a variety of goals and resort to a variety of techniques to accomplish those goals, 'success' can be understood broadly. It can encompass not only a success in getting proposals accepted by other governments and enshrined in the declarations and possibly in the Convention but also success in blocking other governments' proposals that do not fit their own agenda. ${ }^{52}$ Success can also manifest itself in getting the Court to change its practice, through signalling dissatisfaction or through treaty amendment.

The analysis of conference proceedings revealed that the governments of states that had failed to solve structural problems affecting thousands of individuals,

${ }^{51}$ Hirschman, supra n. 10.

${ }^{52}$ As an example, the Russian Federation delayed the ratification of Protocol no. 14 by four years: A. Burkov, 'Russia and the European Court of Human Rights', CEPS Commentary, 10 May 2010, 〈https://www.ceps.eu/wp-content/uploads/2013/02/May\%20Burkov\%20on\%20Russia\%20and\% 20the\%20ECHR.pdf), visited 4 November 2021. 
thereby massively contributing to the Court caseload, ${ }^{53}$ successfully used voice (reform process) to keep costs of membership in the Convention system low by averting more effective supranational enforcement. ${ }^{54}$ The enforcementenhancing reform could have made the failure to comply fully and in a timely fashion with the Court judgments costlier for these governments, if additional powers and resources had been given to the Court or if supervisory mechanisms had been reinforced. Even in the absence of any major treaty change, Court judgments could have become more prescriptive and give clearer instructions on how to proceed with implementation, ${ }^{55}$ and the Committee of Ministers more rigorous in its supervision, in cases of long-term delays in implementation. Unsurprisingly, conference proceedings reveal that governments from this first group either openly opposed the proposals that could strengthen the Court ${ }^{56}$ or supervision mechanisms ${ }^{57}$ or simply refused to support their inclusion in the declarations. ${ }^{58}$ Failure to reinforce the Convention machinery meant continued toleration of partial or selective compliance with the Court judgments. In the absence of (financial or other) sanctions for delays in implementation, ${ }^{59}$ judgments that required the solving of systemic or structural problems remain pending for years, and in any case, longer than can be considered reasonable. ${ }^{60}$ The Court

\footnotetext{
${ }^{53}$ See, e.g., states with major structural/systemic problems and worrying delays in implementation such as the Russian Federation, Turkey, Ukraine, Romania, Poland, Italy, Bulgaria, Greece, and Moldova (European Court of Human Rights: statistics, AS/Jur/Inf (2011) 05 rev 2, 18 April 2011).

${ }^{54}$ The Russian Federation, Turkey, Italy, Bulgaria, and Romania were particularly proactive in this regard.

${ }^{55} \mathrm{H}$. Keller and C. Marti, 'Reconceptualizing Implementation: The Judicialization of the Execution of the European Court of Human Rights' Judgments', 26 EJIL (2015) p. 829.

${ }^{56}$ One may recall Italy's statement in Interlaken, 'there is no need to focus on an increase in resources, but rather to encourage the Court to focus its own efforts on the pursuit of good practices aimed at achieving the right balance between costs and benefits'.

${ }^{57}$ For example, at the Brussels Conference, Bulgaria and the Russian Federation demanded greater subsidiarity in the Committee of Ministers' supervision.

${ }^{58}$ In Interlaken and Brighton, the Norwegian delegation expressed regret that 'the majority of member states have not been willing to provide the Court with additional resources'. Many governments were 'hesitant to support measures' allowing reactions against states that fail to implement judgments in a timely manner, to reverse the increasing number of judgments pending under the Committee of Ministers' supervision for more than five years.

${ }^{59}$ The Convention does not envisage workable mechanisms to sanction governments for delays in implementation. The infringement proceedings, introduced by Protocol no. 14, emerge as an exceptional measure, the target of which will be carefully chosen. Even more radical and unlikely is the resort to the sanctioning procedures under the Council of Europe Statute.

${ }^{60} \mathrm{G}$. Stafford, 'The Implementation of Judgments of the European Court of Human Rights: Worse Than You Think - Part 2: The Hole in the Roof', EJIL:Talk!, 8 October 2019, 〈https:// www.ejiltalk.org/the-implementation-of-judgments-of-the-european-court-of-human-rights-worsethan-you-think-part-2-the-hole-in-the-roof/ $\rangle$, visited 4 November 2021.
} 
has not expanded its prescriptive approach beyond a handful of cases over the years. ${ }^{61}$ The degree of scrutiny exercised by the Committee of Ministers does not appear to have changed significantly either. ${ }^{62}$ Since these governments succeeded at maintaining the status quo, exit became less pressing and hence, more unlikely. They could continue benefiting from participation in the Convention system while keeping costs of membership as low as possible. Notably, governments from this group were not necessarily opposed to the measures that could help reduce the Court's caseload, as long as these measures did not create an additional financial burden. For example, a few insisted that the Court was not to award compensation to successful applicants, as the prospect of receiving compensation incentivised individuals to file applications. ${ }^{63}$

The second group of governments (featuring the Netherlands, Norway, Ireland, Cyprus and Slovenia, most prominently) called for decisive action to solve the implementation crisis and advanced proposals to strengthen the Convention machinery. They proposed allocating additional resources to the Court and separating its budget from that of the Council of Europe. ${ }^{64}$ They called for reinforcement of the role and capacity of the Committee of Ministers. ${ }^{65} \mathrm{~A}$ few emphasised the need for a more stringent reaction to the failure to implement judgments in a timely manner ${ }^{66}$ and stressed the need to provide the Committee of Ministers with 'all necessary tools to insist on full compliance' where 'a lack of political will or pockets of resistance' lead to a failure to execute judgment. ${ }^{67}$ It appears that these proposals did not enjoy widespread support and were left out of the declarations. The statements made at the conferences reveal

${ }^{61}$ Prescriptive judgments remained a small fraction of the overall number of adverse judgments, see A. Donald and A.K. Speck, 'The European Court of Human Rights' Remedial Practice and Its Impact on the Execution of Judgments', 19 Human Rights Law Review (2019) p. 83 at p. 88.

${ }^{62}$ It was only in late 2017 that the Committee of Ministers initiated infringement proceedings (introduced by Protocol no. 14) for the first time in ECtHR 13 October 2014, No. 15172/13, Mammadov v Azerbaijan.

${ }^{63}$ In Interlaken, Turkey (and similarly Italy) argued that the Court as a 'standard-setting institution' should award compensation only exceptionally, and the amounts of just satisfaction should not incentivise applicants. In Brighton, Bulgaria called for a review of the practice of awarding just satisfaction and insisted that in many cases the recognition of the violation should be sufficient.

${ }^{64}$ In Interlaken, the Norwegian, Cypriot and Slovenian delegations called for the provision of additional resources to the Court, possibly by creating a separate budget to strengthen its financial and administrative independence.

${ }^{65}$ For example, in Izmir and Brighton, the Dutch delegation emphasised that the Committee of Ministers 'should play a more active role'.

${ }^{66}$ At the Brighton Conference, Norway welcomed 'proposals to consider further reactions against States that fail to implement judgments in a timely manner' and expressed disappointment 'that many member states are hesitant to support such measures'.

${ }^{67}$ Ireland, Lithuania and Latvia made this point in Brussels. 
frustration due to the hesitation of other governments to support more 'ambitious' measures. However, these governments appear to have succeeded at blocking or watering down changes proposed by other governments that would, in their view, undermine the Court. ${ }^{68}$ Also, their satisfaction with the reform progress can be derived from the success of measures aimed at managing the caseload and solving the crisis. Therefore, one can conclude that their engagement in the reform process has been relatively successful.

The governments from the third group (most prominently, the UK, but also Portugal, Switzerland, Spain) criticised the Court for overreaching and for its lack of deference to national courts and parliaments that acted responsibly. This sentiment shifted the focus of the reform process from efficiency (capacity to process cases within a reasonable time) and effectiveness (facilitation of implementation to limit the number of repetitive cases) of the Court to the issue of division of responsibilities and the appropriate role of the Court. ${ }^{69}$ The principle of subsidiarity and margin of appreciation came to the forefront of the reform debate in Brighton. The draft document leaked to the media was perceived as an attempt to constrain the Court. ${ }^{70}$ Not all proposals advanced in Brighton made it to the text of the declaration. ${ }^{71}$ The compromise solution was to 'encourage' the Court to apply principles such as subsidiarity and the margin of appreciation consistently in its judgments. ${ }^{72}$ The governments from this group had to witness the exercise of greater self-restraint by the Court in order to perceive that voice was effective, and thus they could remain committed to the system. Most recently, at the Copenhagen Conference, governments welcomed jurisprudential developments showing the willingness of the Court to defer to diligent authorities and expressed the hope of seeing further evolution in this regard, allowing 'national democratic systems choose to secure and balance rights in different, but equally legitimate ways. ${ }^{73}$ Such statements signal that these governments perceived voice as

${ }^{68}$ The draft declarations prepared by host governments were toned down considerably: Gerards and Lambrecht, supra n. 41; Glas, supra n. 13.

${ }^{69}$ I.G. Ramanzini and E. Yildiz, 'Revamping to Remain Relevant: How Do European and InterAmerican Human Rights Systems Adapt to Challenges?', 12(3) Journal of Human Rights Practice (2020) p. 768.

${ }^{70}$ E. Bates, 'The Brighton Declaration and the "Meddling Court"', UK Human Rights Blog, 22 April 2012, 〈https://ukhumanrightsblog.com/2012/04/22/the-brighton-declaration-and-themeddling-court/ $\rangle$, visited 4 November 2021.

${ }^{71}$ For example, a new admissibility criterion relating to cases properly considered by national courts encountered opposition during negotiations (Milner, supra n. 13).

${ }^{72}$ See Brighton Declaration, paras 11-12. The Preamble to the Convention was amended by Protocol No. 15 to reflect these principles.

${ }^{73}$ The UK delegation in Copenhagen (2018). 
generally effective, ${ }^{74}$ even though the judicial approach remained under review. This meant that (perceived) judicial responsiveness might have helped avoid exit.

Beyond this demand for conditional deference, these governments were not necessarily opposed to the measures aimed at improving the quality of judges or that of the judicial selection procedures and also the measures reinforcing supervision mechanisms. Hence, in this respect, one may observe some overlapping between the agendas of the second and the third groups.

To sum up, our analysis of governments' evaluations of the reform progress has shown that they considered their engagement in the reform process to be sufficiently effective to warrant the continuation of efforts, even if their goals had not been fully achieved. We argue that a radical push towards either further strengthening or constraining the Court could have led to the exit of some states. A careful incremental approach to the reform appears to have been the key to avoiding exit. The reform has proceeded in small steps, without crossing any red lines and antagonising governments unnecessarily. The Court has successfully handled the back$\log$ of clearly inadmissible cases. ${ }^{75}$ The failure of a handful of states to solve structural problems still remains an issue, ${ }^{76}$ with over $70 \%$ of pending applications coming from these states. ${ }^{77}$ Under-performing governments (mostly newer member states) managed to keep membership costs low by blocking measures aimed at strengthening the Court or reinforcing the mechanisms of supervision. This meant that they could get away with not implementing specific judgments fully ${ }^{78}$ or pick and choose which judgments to implement. If unreasonable delays

\footnotetext{
${ }^{74} \mathrm{~A}$ few scholars have suggested that since the Brighton Conference the Court has become more deferential towards consolidated democracies but is less inclined to defer to states with less established democratic credentials (Madsen, supra n. 13; Ø. Stiansen and E. Voeten, 'Backlash and Judicial Restraint: Evidence from the European Court of Human Rights', 64 International Studies Quarterly (2020) p. 770).

${ }^{75}$ The stock of clearly inadmissible applications has been decreased, from 74,900 (2009) and over 100,000 (2011) to 4,750 (2018), by the use of the single judge procedure introduced by Protocol no. 14, by setting up the filtering section, and by the streamlining of working methods within the Court in respect of this category of cases (Contribution of the $\mathrm{CDDH}$ to the evaluation provided for by the Interlaken Declaration, $1363^{\text {rd }}$ meeting, 11 December 2019, para 106).

${ }^{76}$ Despite progress made during the Interlaken Process, the national implementation 'still remains one of the principal challenges facing the Convention system' (Contribution of the $\mathrm{CDDH}$ to the evaluation provided for by the Interlaken Declaration, $1363^{\text {rd }}$ meeting, 11 December 2019, para. 225).

${ }^{77}$ G. Raimondi, 'Solemn Hearing for the Opening of the Judicial Year of the European Court of Human Rights' 2 〈https://www.echr.coe.int/Documents/Speech_20190125_Raimondi_JY_ENG. pdf $\rangle$, visited 4 November 2021.

${ }^{78}$ The Committee of Ministers was criticised for approving minimalistic compliance with the Court's judgment on prisoners' voting. See E. Adams, 'Prisoners' Voting Rights: Case Closed?', UK Constitutional Law Blog, 30 January 2019, 〈https://ukconstitutionallaw.org/〉, visited 4 November 2021.
} 
in implementation had been properly sanctioned, these governments would have been more inclined to (consider) exit. It seems that beyond the general emphasis on the problem of poor implementation, other governments were also not particularly insistent on tightening the grip over those who were under-performing, as long as the Court was not too overwhelmed and remained functional. Such concessions can be explained by the interest in keeping those states in so that their legal systems can be adjusted slowly and transformed over time. ${ }^{79}$ It appears that the Court's efforts at managing the caseload were central to the (perceived) success of the reform. Governments praised its ability to adapt to challenging circumstances ${ }^{80}$ and transform its working methods for greater efficiency. ${ }^{81}$

\section{High costs of exit as a deterrent}

In order to withdraw from the Convention (and the Court's jurisdiction), governments only need to notify the Secretary General of the Council of Europe and wait for six months. ${ }^{82}$ Hence, exit is not, in itself, procedurally complicated. However, governments may incur at least three types of losses if they exit: one of them is the loss of opportunities to participate in an organisation in which the international court is embedded. ${ }^{83}$ Membership of the Council of Europe is tied to recognition of the Court's jurisdiction. ${ }^{84}$ The probability of exit from the Court decreases because this would entail leaving the Council of Europe too. Moreover, 27 out of 47 Council of Europe member states are, at the same time, EU members for whom a withdrawal from the Convention might

${ }^{79} \mathrm{P}$. Leuprecht, 'Innovations in the European System of Human Rights Protection: Is Enlargement Compatible with Reinforcement', 8 Transnational Law and Contemporary Problems (1998) p. 313 at p. 329-330; W. Sadurski, 'Partnering with Strasbourg: Constitutionalisation of the European Court of Human Rights, the Accession of Central and East European States to the Council of Europe, and the Idea of Pilot Judgments', 9 Human Rights Law Review (2009) p. 397 at p. 410-411 (pointing out that less than ready applicants were accepted as Council of Europe members because it is better to have them in rather than out, so that they were brought fully up to standard through judicial and political pressure).

${ }^{80}$ Denmark, Ireland, Switzerland and France emphasised adaptability.

${ }^{81}$ The governments of Austria, Ireland, Norway, Denmark, Estonia, Finland and several others applauded the willingness of the Court to increase its efficiency, make the best use of the resources available and develop specific mechanisms to reduce the caseload, such as the pilot judgment procedure, use of friendly settlements and unilateral declarations.

${ }^{82}$ Art. 58(1) Convention.

${ }^{83}$ Pauwelyn and Hamilton, supra n. 3, p. 11.

${ }^{84} \mathrm{An}$ undertaking to sign the Convention and accept its supervisory machinery was a fundamental condition in the context of enlargement (Vienna Declaration of 9 October 1993, para. 2, reprinted in 14 Human Rights Law Journal (1993) p. 373). 
hypothetically have some further repercussions. ${ }^{85}$ With states that are not or are no longer members of the EU, the interest in cooperating with the EU may explain the decision to be/remain under the Court's jurisdiction if continued cooperation is conditional on such commitment. Taking into account the EU demands, withdrawal from the Convention appears to have become harder (more costly) for the UK post-Brexit. ${ }^{86}$

Second, the likelihood of a backlash from domestic audiences in favour of international courts can also work as a barrier to exit. ${ }^{87}$ This would apply to a subset of states that have joined the international court to signal to domestic audiences their commitment to human rights. Arguably, the greater the international court's legitimacy and the less trustworthy the national authorities, the more difficult it will be for governments to justify to domestic audiences their withdrawal from the international court. ${ }^{88}$ To decrease costs of exit, governments may seek to discredit the Court by criticising its judgments. ${ }^{89}$ These delegitimising strategies may, however, be more successful in countries with well-functioning national institutions than in countries with poorly performing ones. ${ }^{90}$ The legitimacy losses (and, ultimately, exit) can be avoided if the Court develops its case law and procedures cautiously, avoiding antagonising relevant actors unnecessarily.

Finally, as noted above, Hirschman's framework assumes that exit is likely where consumers can easily switch to a similar product or service. We interpreted this logic to mean that governments may exit the international court more easily if

${ }^{85}$ See the answer by the European Commission: 'Any Member State deciding to withdraw from the Convention and therefore no longer bound to comply with it or to respect its enforcement procedures could, in certain circumstances, raise concern as regards the effective protection of fundamental rights by its authorities. Such a situation, which the Commission hopes will remain purely hypothetical, would need to be examined under Articles 6 and 7 of the Treaty on European Union': European Parliament, Parliamentary questions: Answer given by Mr Frattini on behalf of the Commission, 26 January 2007, 〈http://www.europarl.europa.eu/sides/getAllAnswers.do? reference $=\mathrm{E}-2006-5000 \&$ language $=\mathrm{GA}\rangle$, visited 4 November 2021 .

${ }^{86}$ Cowell, supra n. 49.

${ }^{87}$ Boehme, supra n. 5, p. 425.

${ }^{88}$ B.A. Simmons and A. Danner, 'Credible Commitments and the International Criminal Court', 64 International Organization (2010) p. 225 (suggesting that the states that have independent domestic mechanisms of accountability will join international courts, over which they have no control, to signal credibility of commitment). For example, even the Court's harshest critics in the Russian Federation do not support a Russian withdrawal due to reputational costs and the loss of a venue where one can lodge complaints against a state's human rights violations: G.A. Nelaeva et al., 'Russia's Relations with the European Court of Human Rights in the Aftermath of the Markin Decision: Debating the "Backlash", 21 Human Rights Review (2020) p. 93 at p. 106.

${ }^{89}$ S. Dothan, 'How International Courts Enhance Their Legitimacy', 14 Theoretical Inquiries in Law (2013) p. 455.

${ }^{90} \mathrm{~B}$. Cali et al., 'The Legitimacy of Human Rights Courts: A Grounded Interpretivist Analysis of the European Court of Human Rights', 35 Human Rights Quarterly (2013) p. 955. 
they are able to create an alternative mechanism or join an already existing one to get the same service or benefit. Exit will be unlikely if there is no such mechanism and creating a new one is unrealistic or too costly. As regards the Court, there is no alternative human rights mechanism with comparable reputational cachet to which governments could switch. The decisions of the UN treaty bodies, while authoritative, have no binding force and enforcement machinery and hence, are not comparable to the Court. While in 2011 Russian MPs proposed the Commonwealth of Independent States human rights court as an alternative to the Court, ${ }^{11}$ this initiative was not followed up. It seems that most governments did not view the establishment of an alternative mechanism as politically and/or financially feasible or reasonable.

To sum up, the case study on the Court shows that governments dissatisfied with the international court's performance might choose voice over exit, not only because of the expected effectiveness of voice, but also because of the high costs associated with the exit. As argued above, exit from the Court has been precluded by expected political and reputational losses, especially due to the absence of any system governments could switch to. Even if the use of voice is not as effective as expected, costs of exit can still preclude exit up to the point when membership in the system becomes more expensive than the costs of exit. Governments can reduce the cost of exit by exploring alternative mechanisms or adopting hostile rhetoric towards the Court at the domestic level.

\section{Loyalty}

As noted above, according to Hirschman, members may stay with an underperforming organisation because of loyalty (attachment to that organisation), even if exit is possible and not too costly and even if prospects of effective use of voice are uncertain. ${ }^{2}$ It does not mean that exit is entirely out of the question. However, loyalty postpones exit and can help activate voice, giving an organisation a chance to recuperate. Loyalty may have even greater significance for international courts than it has for companies or parties, because securing change in relevant law and practice is bound to take time, and results will not be immediately visible. When the Court's performance deteriorated, governments' decision not to exit must have been rooted in loyalty to the Court or to the values it had been established to advance. While states with well-functioning independent

\footnotetext{
${ }^{91}$ S. Huntley, 'ECHR and Promotion of the Rule of Law in Russia: The CIS Human Rights Court: A Possible Alternative to the ECHR?', ECHR and Promotion of the Rule of Law in Russia, 5 October 2011 〈http://echrrussia.blogspot.com/2011/10/cis-human-rights-courtpossible.html $\rangle$, visited 4 November 2021.

${ }^{92}$ Hirschman, supra n. 10 , p. $38,77,81$.
} 
judiciaries could have exited the (under-performing) Court without experiencing major reputational and other losses, they could have been concerned about the broader implications of such an exit, namely the likelihood of states with poor human rights records following suit and exiting as well. ${ }^{93}$ One may recall that the anti-Court rhetoric in the UK gave rise to similar sentiments in the Russian Federation, Poland and Hungary. ${ }^{94}$ Hence, the non-exit of certain governments can be explained by a concern about the human rights situation beyond their borders. ${ }^{95}$ This concern was arguably a driving force behind the enlargement of the Council of Europe. The Court was seen as a key player in promoting the Council of Europe values in newer member states. ${ }^{96}$ Older member states must have remained committed to fixing the system so that the Court could intervene where it was needed most while at the same time deferring to well-functioning institutions that acted responsibly.

Hirschman suggests that loyal members who are influential can actively use voice to change international court practices, while others will passively wait for the situation to improve. ${ }^{97}$ This means that not all members that decide against exit and remain committed will actually use voice. Our study of Court reform proceedings showed the need for this basic framework to be fine-tuned: loyalty-driven responses have ranged from the active use of voice, to relative silence, to the defence of the Court against uses of voice believed to be damaging. We argue, however, that because of the diverse interests of governments, 'overdoing' voice or defence efforts can ultimately trigger exit. This brings us again to the necessity for caution and balance in the implementation of the reforms highlighted above.

${ }^{93} \mathrm{P}$. Leach and A. Donald, 'Russia Defies Strasbourg: Is Contagion Spreading?', EJIL: Talk!, 19 December 2015, 〈https://www.ejiltalk.org/russia-defies-strasbourg-is-contagion-spreading/〉, visited 4 November 2021.

${ }^{94} \mathrm{M}$. Amos, 'The Value of the European Court of Human Rights to the United Kingdom', 28 EJIL (2017) p. 763 at p. 775.

${ }^{95}$ See, e.g., Camerson, supra n. 40. Interestingly, it seems that the democracy promotion role does not win the Court support of the British public: E. Dinas and E. Gonzalez-Ocantos, 'Defending the European Court of Human Rights: Experimental Evidence from Britain', 60 European Journal of Political Research (2020) p. 397, 〈https://doi.org/10.1111/1475-6765.12404 , visited 4 November 2021.

${ }^{96}$ According to the Preamble of the Convention, human rights protection serves as a 'foundation of justice and peace'. The Preamble also contains references to the like-mindedness of the governments of the European countries and the common heritage of political traditions, ideals, freedom and the rule of law.

${ }^{97}$ Hirschman, supra n. 10 , p. 38. 


\section{Conclusions: A LOOK AT THE COURT AND BEyond}

Drawing on Hirschman's framework, we identified three key factors that can explain governments' decisions to not exit the Court's jurisdiction despite high levels of dissatisfaction with its performance, and to use voice (i.e. criticise the Court and call for changes) instead. These factors are: (a) the perceived effectiveness of voice; (b) the high costs of exit; and (c) loyalty to the Court or to values it was established to promote.

We argued that governments dissatisfied with the Court's performance may contemplate exiting its jurisdiction, but it is not a decision that they will take easily and promptly, even if their level of discontent is high. This distinguishes governments from members or customers of the organisations to which the original Hirschman's framework applied. Loyalty to the Court, or to the values it was established to promote, can dissuade certain governments from exiting early on, giving the Court a chance to address the concerns that have been raised. Other governments may be deterred by the high costs of exit. Governments may also be inclined to choose voice over exit because they are not simply beneficiaries of the Court's services - they also enjoy some ownership of the Convention system. Ultimately, continued commitment to the system hinges largely on the perceived effectiveness of voice. The Court might have to adjust its case law and working methods when faced with widespread agreement among governments on the need for such adjustments. Where there is deadlock in the reform process, due to variations in governments' perceptions of the Court's role and their assessments of its performance, the Court's willingness and ability to find creative solutions to the problems identified by governments can help avoid exit. When faced with governments' conflicting expectations, however, the Court may need to be cautious not to antagonise any particular government and trigger exit. From that standpoint, a careful, incremental approach to change can be helpful, as demonstrated by our study. While not all expectations of all governments can realistically be met, exit risks can be reduced down the line if at least some of the desired changes are implemented or if undesirable changes are blocked.

The factors that have worked to the advantage of the Court could have helped to avoid exit in other contexts too, where dissatisfaction was significant enough to warrant a reaction. When applying the framework to other international courts, one needs to ask: (a) Do governments believe that the court in question takes their concerns and suggestions seriously and displays some degree of responsiveness?; (b) Do governments consider the costs associated with exit to be high enough for them to have a deterrent effect?; (c) Does the loyalty of states under the Court's jurisdiction allow the international court to adopt potentially controversial rulings without risking exit, or help to postpone exit if such rulings trigger a backlash, so that it has time to make adjustments? 
As argued above, the success of the Court in exit avoidance was, to a great degree, due to its responsiveness to governments' concerns (effectiveness of voice), even though loyalty to the system or high costs of exit might have worked as a deterrent for some governments as well, especially at the onset of the crisis. Other international courts may choose a different path to avoid exit: instead of engaging in an incremental dialogue with governments and adjusting their own practices to accommodate governmental concerns, international courts may prioritise measures that enhance loyalty or the ones that help increase costs of exit, so that costs of membership in the system fade in comparison. Such a course of action may be explained by a particular political environment, reasons for governments' discontent, the scale of opposition, the amount of support the court in question enjoys among governments and the court's approach to managing its own legitimacy. The Inter-American Court of Human Rights appears to have adopted an approach to exit avoidance that differs from the European Court's. Namely, its strategy appears to be based less on responsiveness and more on making exit more burdensome and politically costly. Most recently, with its decision dated 9 November 2020, ${ }^{98}$ the Inter-American Court has created procedural hurdles for withdrawals. This approach is in line with the Inter-American Court's consistently bold, proactive approach to developing its case law, which stands in contrast with the careful, incremental approach of the European Court. ${ }^{99}$ The success of each of these approaches in actually avoiding exit remains to be seen.

${ }^{98}$ Inter-American Court of Human Rights 9 November 2020, Advisory Opinion OC-26/20. See S. Steininger, 'Don't Leave Me This Way: Regulating Treaty Withdrawal in the Inter-American Human Rights System', EJIL:Talk!, 5 March 2021, 〈https://www.ejiltalk.org/dont-leave-methis-way-regulating-treaty-withdrawal-in-the-inter-american-human-rights-system/ $\rangle$, visited 4 November 2021.

${ }^{99}$ Y. Shany, 'Assessing the Effectiveness of International Courts: A Goal-Based Approach', 106 American Journal of International Law (2012) p. 225. 